Reprod. Nutr. Dévelop., 1988, 28 (1), 163-164.

\title{
The effect of isoacids on ruminal fermentation : in vitro trials
}

\author{
G. PIVA, F. MASOERO, O. CURTO $\left(^{*}\right)$
}

Istituto di Scienze della Nutrizione, (*) Istituto di Chimica sez. Chimica Vegetale. Università Cattolica del Sacro Cuore, Via Emilia Parmense, 84, 29100 Piacenza, Italia.

Summary. Isoacids (isobutyric, isovaleric and valeric acids) showed a stimulating effect on ruminal microflora fermentations, particularly on acetic, propionic and butyric acid production and on microbial protein synthesis. No effects were observed on production of isoacids but the acetic/propionic ratio was decreased by treatments.

Isoacids such as isobutyric, isovaleric and 2-methylbutyric acids, which derive from the catabolism of certain amino acids in the rumen, stimulate the cellulolytic activity of rumen bacteria and protein synthesis (Bentley et al., 1955), either singly or in association (Dehority et al., 1967). In this research we checked the effect of isobutyric, isovaleric and valeric acids and of two mixtures of them at two concentration levels (table 1) on the in vitro fermentative activity of rumen microorganisms.

TABL. 1. - Effect of the lower level of isoacids (24 replicates).

\begin{tabular}{lccccccc}
\hline & \multicolumn{7}{c}{ Treatments $\mathrm{mM} / 100 \mathrm{ml}$} \\
& & 0.74 & 0.64 & 0.64 & 0.68 & 0.68 \\
\hline & & $\begin{array}{c}\text { Iso } \\
\text { Butyric }\end{array}$ & $\begin{array}{c}\text { Iso } \\
\text { Valeric }\end{array}$ & Valeric & Mix (1) & Mix (1) \\
\hline Gas production ml & $24.0 \mathrm{c}$ & $30.4 \mathrm{~b}$ & $29.3 \mathrm{bc}$ & $28.7 \mathrm{bc}$ & $27.3 \mathrm{c}$ & $28.0 \mathrm{bc}$ \\
VFA production mg/100 ml & $102.3 \mathrm{a}$ & $148.1 \mathrm{bc}$ & $112.7 \mathrm{bc}$ & $14.0 \mathrm{bc}$ & $122.9 \mathrm{abc}$ & $119.5 \mathrm{abc}$ \\
Acetic $\mathrm{ac} . \mathrm{mg} / 100 \mathrm{ml}$ & $66.1 \mathrm{abc}$ & $67.2 \mathrm{ab}$ & $46.9 \mathrm{c}$ & $65.9 \mathrm{abc}$ & $54.5 \mathrm{abc}$ & $66.1 \mathrm{abc}$ \\
Propionic ac. $\mathrm{mg} / 100 \mathrm{ml}$ & $33.2 \mathrm{abc}$ & $34.3 \mathrm{abc}$ & $26.5 \mathrm{c}$ & $35.6 \mathrm{abc}$ & $29.2 \mathrm{bc}$ & $27.7 \mathrm{abc}$ \\
Butyric ac. $\mathrm{mg} / 100 \mathrm{ml}$ & $11.4 \mathrm{abc}$ & $13.3 \mathrm{ab}$ & $9.1 \mathrm{c}$ & $13.2 \mathrm{ab}$ & $10.0 \mathrm{bc}$ & $11.4 \mathrm{abc}$ \\
$\mathrm{C}_{2}+\mathrm{C}_{4} / \mathrm{C}_{3} \mathrm{Molar} \% \mathrm{ratio}$ & $3.58 \mathrm{a}$ & $3.54 \mathrm{ab}$ & $3.50 \mathrm{ab}$ & $3.44 \mathrm{~b}$ & $3.59 \mathrm{ab}$ & $3.54 \mathrm{ab}$ \\
Isobutyric ac. $\mathrm{mg} / 100 \mathrm{ml}$ & $1.0 \mathrm{a}$ & - & $0.05 \mathrm{a}$ & $1.25 \mathrm{a}$ & $3.6 \mathrm{a}$ & $1.8 \mathrm{a}$ \\
Isobutric ac. $\mathrm{mg} / 100 \mathrm{ml}$ & $5.9 \mathrm{a}$ & $4.8 \mathrm{a}$ & - & $6.7 \mathrm{ab}$ & $9.5 \mathrm{ab}$ & $6.1 \mathrm{ab}$ \\
Valeric ac. $\mathrm{mg} / 100 \mathrm{ml}$ & $1.8 \mathrm{a}$ & $7.0 \mathrm{ab}$ & $1.7 \mathrm{a}$ & - & $6.0 \mathrm{ab}$ & $6.8 \mathrm{ab}$ \\
TCA proteins $\mathrm{mg} / 100 \mathrm{ml}$ & $16.3 \mathrm{a}$ & $16.7 \mathrm{a}$ & $17.3 \mathrm{a}$ & $16.7 \mathrm{a}$ & $17.4 \mathrm{a}$ & $16.9 \mathrm{a}$ \\
\hline
\end{tabular}

Means in the same row with different letters are statistically different for $P<0.01$.

Material and methods. Six fermentations were carried out with four replicates for each treatment and for the untreated control. Thirty $\mathrm{ml}$ of inoculum $133 \%$ rumen fluid and $66 \%$ buffer) (Menke, 1979), were used for each fermentation syringe. The ruminal inoculum was taken before the first feeding of the morning (8 am), from three heifers fitted with a ruminal fistula and fed a ration of hay, corn silage and concentrate $(40: 40: 20$ and $13 \%$ crude protein on dry matter basis). The substrate used $(666 \mathrm{mg} / 100 \mathrm{ml}$ of inoculum) had the following composition: cellulose $20.0 \%$, starch $67 \%$, glucose $8.0 \%$, urea $4.52 \%$, sodium sulphate $0.49 \%$. Three $\mathrm{ml}$ of fermented liquid were taken from each fermenter for the determination of the volatile fatty acid composition according to 
the method of Jouany (1982). Gas production was measured directly from the syringes in comparison with the gas production of the untreated control. TCA precipitable proteins were determined on the total content of two syringes adding $5 \mathrm{ml}$ of a $50: 50$ (w : v) solution of TCA. The sample was centrifuged for $30 \mathrm{~min}$ at $15,000 \mathrm{xg}$ and the precipitate washed three times before nitrogen determination using the Kjeldhal method. Factorial analysis of variance and the studentized range test were applied to the data.

TABLE. 2. - Effect of the higher level of isoacids (24 replicates).

\begin{tabular}{|c|c|c|c|c|c|c|c|}
\hline & & \multicolumn{6}{|c|}{ Treatments $\mathrm{mM} / 100 \mathrm{ml}$} \\
\hline & & 1.48 & 1.28 & 1.28 & 1.36 & 1.36 & \\
\hline & Control & $\begin{array}{c}\text { Iso } \\
\text { butyric }\end{array}$ & $\begin{array}{c}\text { Iso } \\
\text { valeric }\end{array}$ & Valeric & $\operatorname{Mix}(1)$ & $\operatorname{Mix}(1$ & \\
\hline Gas production ml & $14.7 \mathrm{a}$ & 26.4 & 26.2 & 25.7 & 25.8 & 23.2 & c \\
\hline VFA production $\mathrm{mg} / 100 \mathrm{ml}$ & 79.6 a & 142.5 bcd & $150.6 \mathrm{bc}$ & $144.5 \mathrm{bcd}$ & 175.8 & 141.5 & bcd \\
\hline Acetic ac. $\mathrm{mg} / 100 \mathrm{ML}$ & $22.7 \mathrm{a}$ & $37.8 \mathrm{c}$ & $45.3 \mathrm{bc}$ & 43.7 bc & 57.0 & 40.2 & $\mathrm{c}$ \\
\hline Propionic ac. $\mathrm{mg} / 100 \mathrm{ml}$ & $13.1 \mathrm{a}$ & $20.7 \mathrm{c}$ & $24.6 \mathrm{bc}$ & $24.1 \mathrm{bc}$ & $28.0 \mathrm{~b}$ & $21.2 \mathrm{c}$ & $\mathrm{c}$ \\
\hline Butyric ac. $\mathrm{mg} / 100 \mathrm{ml}$ & $4.7 \mathrm{a}$ & $9.0 \mathrm{bc}$ & $9.3 \mathrm{bc}$ & $9.62 b c$ & $11.4 \mathrm{~b}$ & $8.4 b$ & b \\
\hline $\mathrm{C}_{2}+\mathrm{C}_{4} / \mathrm{C}_{3}$ Molar \% ratio & $3.80 \mathrm{a}$ & $3.66 \mathrm{ab}$ & $3.56 \mathrm{~b}$ & $3.55 \mathrm{~b}$ & $3.63 a b$ & $3.65 \mathrm{a}$ & $a b$ \\
\hline Isobutyric ac. $\mathrm{mg} / 100 \mathrm{ml}$ & $0.8 \mathrm{a}$ & - & $0.8 \mathrm{a}$ & $0.25 a b$ & $2.8 \mathrm{ab}$ & $1.2 \mathrm{a}$ & $a b$ \\
\hline Isovaleric ac. $\mathrm{mg} / 100 \mathrm{ml}$ & 5.9 a & $0.4 \mathrm{ab}$ & - & $14.4 \mathrm{ab}$ & $2.2 \mathrm{ab}$ & $1.1 \mathrm{a}$ & a \\
\hline Valeric ac. $\mathrm{mg} / 100 \mathrm{ml}$ & $2.1 \mathrm{a}$ & $9.6 \mathrm{ab}$ & $2.0 \mathrm{a}$ & - & $2.1 \mathrm{ab}$ & $10 \quad \mathrm{a}$ & a \\
\hline TCA proteins $\mathrm{mg} / 100 \mathrm{ml}$ & $20.9 \mathrm{a}$ & 23.4 bc & $22.9 \mathrm{bc}$ & $23.1 \mathrm{bc}$ & $23.6 \mathrm{c}$ & $23.5 \mathrm{~b}$ & $\mathrm{bc}$ \\
\hline
\end{tabular}

Means on the same row with different letters are statistically different for $P<0.01$.

Results and discussion. Gas production after $6 \mathrm{~h}$ of fermentation was stimulated $(P<0.01)$ by all the treatments at both levels of isoacids and at the higher level gas production was on average greater. At the lower level (table 1) only isobutyric and valeric acid had a positive effect $(P<0.01)$, while at the higher level (table 2) all the treatments stimulated the volatile fatty acid production $(P<0.01)$. The greatest effects on production of propionic acid were given by isovaleric and valeric acid and mix 1 , while butyric acid production was stimulated by all the treatments $(P<0.01)$ but most markedly by mix 1 . An interesting fact to note is that only valeric and isovaleric acids were capable of modifying $(\mathrm{P}<0.01)$ the $\mathrm{C}_{2}+\mathrm{C}_{4} / \mathrm{C}_{3}$ ratio, and, in particular, that valeric acid had the same effect even at the lower level of treatment. No effect on the isoacids produced could be seen. All the treatments, at the higher level, led to an increase $(P<0.01)$ of TCA precipitable proteins. The improvement in fermentative efficiency and in protein synthesis observed in different experiments would seem to be sufficient to explain the positive effect on milk production (Felix, Cook and Huber, 1980).

Research work supported by CNR, Italy. Special grant I.P.R.A. - Sub-project 1. Paper N. 1013.

Bentley O. G., Hohnson R. R., Hershberger T. V., Cline J. H., Moxon A. L., $1955 . \quad J$. am. Chem. Soc., 76, 5000-5001.

Dehority B. A., Scott H. W., Kowaluk P., 1967. J. Bacteriol., 94, 537-543.

Felix A., Cook R. M., Huber J. T., 1980. J. Dairy Sci., 63, 1098-1103.

Jouany J. P., 1982. Sci. Aliments, 2, 131-144.

Menke K. H., Raab L., Salewski A., Steingass H., Fritz D., Scneider W., 1979. J. Agric. Sci. Camb., 93, 217-222. 